\title{
PENGARUH KUALITAS PRODUK, HARGA DAN LOKASI TERHADAP KEPUTUSAN PEMBELIAN (STUDI KONSUMEN UMKM MIE AYAM DAN BAKSO BAROKAH INA KABUPATEN BUNGO)
}

\author{
Delila Fitri Harahab ${ }^{1}$, Yuniar Mryanti ${ }^{2}$ Herawati $^{3}$ \\ ${ }^{123}$ Universitas Muara Bungo \\ fitridelila86@gmail.com
}

\begin{abstract}
ABSTRAK
Penelitian ini bertujuan untuk mengetahui pengaruh kualitas produk, harga dan lokasi terhadap keputusan pembelian studi konsumen UMKM Mie Ayam dan Bakso Barokah Ina di Bungo. Metode penelitian yang digunakan adalah kuantitatif, sumber data yang digunakan adalah data primer dan sekunder. Populasi dalam penelitian ini adalah seluruh konsumen yang membeli di warung Mie Ayam dan Bakso Barokah Ina di Bungo. Sampel yang dalam penelitian ini sebanyak 96 responden dengan pengambilan sampelnya menggunakan teknik accidental sampling. Metode pengumpulan data yang digunakan: wawancara dan kuesioner. Metode analisis data yang digunakan adalah analisis linier berganda dan uji hipotesis menggunakan Uji $t$, Uji F dan koefisien determinasi. Dari hasil analisis uji-t menunjukkan bahwa kualitas produk, harga dan lokasi secara parsial berpengaruh terhadap keputusan pembelian. Hasil uji-F diketahui bahwa kualitas produk, harga dan lokasi secara simultan berpengaruh terhadap keputusan pembelian. Hasil analisis koefisien determinasi diperoleh adjusted $R$ square $\left(R^{2}\right)$ sebesar 0,670, ini dapat diartikan bahwa $67 \%$ perubahan keputusan pembelian dikarenakan oleh adanya perubahan variabel kualitas produk, harga dan lokasi. Sedangkan 33\% sisasnya dikarenakan oleh adanya perubahan variabel lain yang masuk dalam variabel yang diteliti.
\end{abstract}

Kata kunci: kualitas produk, harga dan lokasi

\begin{abstract}
This study aims to analyze the influence of product quality, price and location on purchasing decisions of the UMKM consumer study of Mie Ayam and Bakso Barokah Ina in Bungo. The research method used is quantitative, the data sources used are primary and secondary data. The population in this study were all consumers who had bought at Mie Ayam and Bakso Barokah Ina stalls in Bungo. The sample in this study as many as 96 respondents with sampling taken by using accidental sampling technique. Data collection methods used: interviews and questionnaires. The data analysis method used is multiple linear analysis and hypothesis testing using $t$ test, $F$ test and coefficient of determination. From the results of the $t$-test analysis shows that product quality, price and location partially affect purchasing decisions. The results of the $F$-test show that product quality, price and location simultaneously affect purchasing decisions. The results of the analysis of the coefficient of determination obtained adjusted $R$ square $\left(R^{2}\right)$ of 0.670 , this means that $67 \%$ of changes in purchasing decisions are caused by the changes in product quality, price and location variables. While the remaining $33 \%$ is due to changes in other variables included in the variables studied.
\end{abstract}

Keywords: product quality, price and location

\section{PENDAHULUAN}

Keputusan pembelian oleh konsumen sebenarnya adalah proses pengintegrasian yang mengkombinasikan pengetahuan untuk mengevaluasi dua atau lebih perilaku alternatif dan memilih salah satu diantaranya, di mana hasil dari suatu proses pengintegrasian inilah yang disebut sebagai pilihan (choice) yang disajikan secara kognitif sebagai keinginan untuk berperilaku (Setiadi,2010:33). Keputusan pembelian 
Prosiding The 1st National Conference on Applied Business, Education, \& Technology (NCABET)"

Unversitas Bina Bangsa 2021

DOI Article : 10.46306/ncabet.v1i1.42

dipengarui dari berbagai faktor-faktor sebagai pertimbangan baik yang dapat dipengaruhi oleh factor internal maupun factor eksternal, (Effendi, Harahab, \& Arisandi, 2018). Maka dari itu perusahaan dituntut untuk terus bersaing dalam hal menarik konsumen dan menerapkan strategi yang tepat untuk mencapai target penjualan. Inovasi produk dan krativitas pengusaha yang dapat memenuhi kebutuhan dan keinginan konsumen sangat diperlukan apabila pelaku usaha tidak ingin kehilangan konsumen sehingga dapat menumbuhkan permintaan akan produk tersebut. Penelitian sebelumnya menemukan bahwa inovasi dalam pengemasan produk dapat meningkatkan penjualan produk UMKM disesa Kuamang Gading, kota Jambi, (Effendi, Supriyati, \& Herawati, 2021), Dalam mempertahankan dan menumbuhkan permintaan baru bukanlah perkara mudah bagi para pelaku usaha di zaman pandemic saat ini.

Dewasa ini, perkembangan dunia kuliner di Indonesia telah mengalami perkembangan yang cukup pesat. Banyak para pelaku usaha yang mencoba untuk menggeluti usaha di dunia kuliner dengan menciptakan suatu inovasi dan kreasi baru produknya, mengingat kuliner merupakan salah satu bentuk UMKM dimana keberadaannya menjadi penyangga ekonomi Negara, (Effendi, 2021). Perilaku masyarakat yang menyukai kegiatan mencoba wisata kuliner dari satu tempat ke tempat makan yang lainnya berkembang cepat seiring dengan menjamurnya aneka jajanan kuliner berbagai jenis dan bentuk yang unik. Hal tersebut disebabkan oleh berbagai faktor, diantaranya adalah gaya hidup orang-orang zaman sekarang yang gemar dalam mengeksplor aneka jenis kuliner atau tempat kuliner yang dijadikan sarana untuk bersosialisasi serta bagi kaum muda untuk mencari spot kuliner dengan tempat yang nyaman dan harga terjangkau. Selain itu, internet yang sudah tersebar luas juga menjadi pendorong masyarakat menjadi lebih mudah dalam mendapatkan informasi lokasi dan produk yang sesuai tanpa menyita waktu, (Effendi, Akbar, \& Murni, 2020)

Salah satu tempat usaha kuliner di kabupaten Bungo yang digemari oleh kalangan masyarakat adalah UMKM Mie Ayam dan Bakso Barokah Ina adalah bakso beranak dan Bakso mangkok yang berbeda dari bakso lainnya. Bapak Ebit Supardi adalah pemilik sekaligus pengelola UMKM Mie Ayam dan Bakso Barokah Ina, Beliau memulai usaha berdagang mie ayam dan bakso sekitar tahun 2012. UMKM Mie Ayam dan Bakso Barokah Ina beralamat di Jl. Durian No.1A, Rt.001, Talang Pantai, Bungo Dani.

UMKM Mie Ayam dan Bakso Barokah Ina dapat menjual minimal 80 magkuk sehari dan 200 mangkuk pada saat pengunjung ramai. Pendapatan UMKM Mie Ayam dan Bakso Barokah Ina minimal Rp 1.200.000,00 sehari saat sepi dan mencapat 
Prosiding The 1st National Conference on Applied Business, Education, \& Technology (NCABET)"

Unversitas Bina Bangsa 2021

DOI Article : 10.46306/ncabet.v1i1.42

Rp.2.500.000,00 sehari saat ramai pengunjung. UMKM Mie Ayam dan Bakso Barokah Ina buka dari pukul 09.00 WIB hingga 23.00 WIB.

UMKM Bakso Barokah Ina yang menawarkan bentuk bakso yang berbeda dari bakso pada umumnya, biasanya bakso pada umumnya hanya terdapat bakso yang berukuran kecil, sedang dan besar sedangkan UMKM Mie Ayam dan Bakso Barokah Ina memiliki menu berbeda yaitu bakso beranak dan bakso mangkok. Bakso beranak memiliki ukuran yang jumbo dan dalam bakso tersebut terdapat lagi bakso kecil dan telur puyuh yang membuat kesan berbeda dari bakso biasanya. Sedangkan bakso mangkok memiliki ukuran yang lebih besar dari bakso beranak dengan isian lebih bervariasi dan didalam nya terdapat lebih banyak bakso kecil dan telur puyuh. Sedangkan Mie ayam yang di tawarkan menggunakan bahan baku mie yang diproduksi sendiri oleh pemiliknya. UMKM Bakso Barokah Ina selama 3 bulan terakhir mengalami fluktuasi, hal tersebut karena UMKM Bakso Barokah Ina menghadapai persaingan yang kompetitif, terutama persaingan yang berasal dari usaha sejenis maupun usaha kuliner yang lain. Hal tersebut sesuai dengan konsep pemasaran yang menyebutkan bahwa kesuksessan suatu perusahaan ditentukan oleh usaha perusahaan dalam memenuhi kebutuhan dan keinginan konsumen, sehingga dapat memberikan kepuasan yang diinginkan lebih daripada pesaing (Leon G.Schiffman dan Leslie L.Kanuk, 2008:5).

Konsumen saat melakukan pembelian mempertimbangkan kualitas produk dalam hal ini makanan yang akan dibeli. Faktor kualitas produk merupakan salah satu faktor penentu seberapa tingkat kepuasan yang akan didapat oleh konsumen setelah melakukan pembelian dan penggunaan terhadap suatu produk. Dengan kualitas produk yang baik maka konsumen akan terpenuhi kebutuhan dan keinginannya akan suatu produk.

Dalam melakukan keputusan pembelian biasanya hal pertama yang dipertimbangan konsumen dalam memilih produk adalah dengan melihat harga atas produk tersebut(Ananda, Putra, \& Hendrastyo, 2017; Ananda \& Zulvia, 2018). Menurut Mowen dan Minor dalam Bekti Setiawati (dikutip oleh Septhani, 2011) menyatakan bahwa harga adalah atribut paling penting yang dievaluasi oleh konsumen dan factor penentu dalam keputusan pembelian, (Miftahur, Effendi, \& Roni, 2018). Oleh karena itu, seorang manajer perusahaan perlu benar-benar menyadari peran tersebut dalam menentukan sikap konsumen.

Selain kualitas produk, hal yang perlu diperhatika oleh UMKM Mie Ayam dan Bakso Barokah Ina adalah dengan mempertimbangkan dalam hal harga produk itu sendiri, karena sesuia hasil wawancara dengan konsumen diketahui bahwa bakso yang dijual hargaya lebih mahal dari bakso yang lainnya. Harga bakso yang lebih mahal 
dikarenakan menurut pemilik yaitu Ebit Supardi dilihat dari segi biaya oprasional yang lebih tinggi mulai dari produksi menggunakan daging sapi pilihan dan penggunaan mie yang diproduksi menggunkaan bahan yang berkualitas tinggi. Bukan hanya itu pemilik mengatakan bahwa diperlukan biaya pemeliharaan dan sewa tempat dengan menyediakan tenpat yang nyaman, lokasi mudah dijangkau dan parkir yang cukup luas.

Faktor lokasi juga berpengaruh terhadap keputusan yang diambil konsumen untuk membeli suatu produk. Lokasi yang mudah dijangkau oleh konsumen dan dekat dengan pusat keramaian merupakan lokasi yang tepat untuk suatu usaha, termasuk usaha warung Bakso dan Mie ayam. Sebelum seseorang/sekelompok orang memutuskan untuk makan di suatu warung makan, mereka juga akan mempertimbangkan lokasi tempat makan tersebut. Sebagian besar orang lebih memilih lokasi tempat makan yang dekat dari rumah/ kantor mereka.

Keputusan pembelian menurut Leon G.Schiffman dan Leslie L.Kanuk(2008:47) adalah pemilihan dari duan atau lebih alternatif pilihan keputusan pembelian, artinya bahwa seseorang dapat memebuat keputusan, haruslah tersedia beberapa alternatif pilihan. Keputusan untuk membeli dapat mengarah kepada bagaimana proses dalam hal pengambilan keputusan tersebut untuk dilakukan. Banyak faktor yang menjadi pertimbangan konsumen dalam memutuskan untuk membeli suatu produk. Sehingga pelaku usaha harus jeli dalam melihat faktor-faktor apa saja yang harus diperhatikan untuk menarik konsumen.

Tujuan penelitian ini adalah: 1) untuk mengetahui pengaruh Kualitas Produk, Harga dan Lokasi secara parsialterhadap keputusan Pembelian studikonsumen UMKM Mie Ayam dan Bakso Barokah Ina di Kabupaten Bungo, 2) untuk mengetahui pengaruh Kualitas Produk, Harga dan Lokasi secara simultan terhadap keputusan Pembelian studikonsumen Mie Ayam dan UMKM Bakso Barokah Ina di Kabupaten Bungo.

\section{Kerangka Pemikiran}

Untuk menunjukka suatu arah dari penyusunan sehingga dapat memperoleh pandangan yang lebih jelas, maka dalam penelitian ini penulis membuat kernangka pemikiran. Kerangka pemikiran ini yaitu seperti gambar dibawah ini:

Hipotesis Penelitian

$\mathrm{H}_{1} \quad$ : Terdapat Pengaruh yang signifikan kualitas produk, harga, lokasi secara parsial terhadap keputusan pembelian.

$\mathrm{H}_{2}$ : Terdapat pengaruh yang signifikan kualitas, harga dan lokasi secara simultan terhadap keputusan pembelian. 
Keterangan :

1. Variabel Independen (Bebas)

Variabel bebad adalah variabel yang mempengaruhi variabel terikat, yang termasuk varibel bebas yaitu kualitas produk, harga dan lokasi.

2. Variabel Dependen (Terikat)

Variabel terikat adalah variabel yang dipengaruhi oleh variabel bebas dalam ha ini keputusan pembelian.

\section{METODE PENELITIAN}

Metode penelitian menggunakan metode survei, jenis data yang digunakan yaitu data kuantitatif, sumber data yang digunakan data primer dan sekunder. Populasi dalam penelitian ini yaitu seluruh konsumen UMKM Mie Ayam dan Bakso Barokah Ina di Bungo. Jumlah sampel sebanyak 96 responden, dengan teknik pengambilan sampel menggunakan teknik accidental sampling. Metode pengumpulan data yang digunakan: wawancara dan kuesioner.

Definisi operasional variabel dan pengukurannya adalah sebagai berikut:

1. Kualitas Produk

Kualitas produk adalah Karakteristik dan ciri produk UMKM Mie Ayam dan Bakso Barokah Ina untuk memuaskan kebutuhan konsumen. Indikator-indikator variabel kualitas produk dalam penelitian ini mengacu pada teori yang dikemukakan Kotler, 2005, meliputi:

1. Variasi menu

2. Rasa dari poruk yang disajikan

3. Tata penyajian produk.

2. Harga 
Harga adalah sejumlah uang yang dibebankan atas pembelian di UMKM Mie Ayam dan Bakso Barokah Ina untuk mendapatkan manfaat-manfaat memiliki dan menggunakna produk tersebut. Indikator variabel harga dalam pnelitian ini mengacu pada teori yang dikemukakan Kotler \& Amstrong, 2006 meliputi:

1. Harga sesuai dengan kemampuan membeli konsumen.

2. Kesesuaian harga dengan kuantitas produk

3. Harga kompetitif bila dibandingkan dengan produk lain yang sejenis.

\section{Lokasi}

Lokasi adalah suatu tempat dimana kegiatan-kegiatan UMKM Mie Ayam dan Bakso Barokah Ina untuk membuat produk dapat diperoleh dan tersedia bagi konsumen.

Indikator variabel lokasi dalam penelitian ini mengacu pada toeri yang dikemukakan Kotler,2007 meliputi:

1. Mudah dijangkau

2. Parkir yang luas dan aman

3. Dekorasi/Interior

4. Keputusan Pembelian

Keputusan pembelian adalah suatu usaha yang dilakukan oleh konsumen untuk membeli suatu barang atau jasa yang dimulai untuk pemenuhan kebutuhan dan diakhiri dengan melakukan seleksi atas alternatif-alternatif mengenai barang atau jasa yang ada. Variabel keputusna pembelian diukur dengan menggunakna skal likert. Indikator-indikator variabel keputusan pembelian mengacu pada teori Kotler, 2007 meliputi:

1. Pengenalah masalah

2. Pencarian informasi

3. Penilaian alternatif

4. Keputusan pembelian

5. Perilaku setelah membeli

Penelitian ini menggunakan data yang bersumber dari data primer, yaitu data yang diperoleh secra langsung dari responden melalui jawaban kuesioner. Teknik pengumpulan data menggunakan skal likert lima poin adalah mulai dari Sangat Setuju $(\mathrm{SS}=5)$, Setuju $(\mathrm{S}=4)$, Kurang Setuju $(\mathrm{KS}=3)$, Tidak Setuju $(\mathrm{TS}=2)$, Sangat Tidak Setuju (STS = 1).

Pengujian validitas instrumen dilakukan dengan menggunakan rumus Korelasi person, kriteria pengujiannya menggunakan tingkat signifikansi $\alpha=0,05$, dengan pengujian 2-tailed. Butir instrumen dinyatakan valid jika $r_{h i t u n g}>r_{\text {tabel}}$. Pengujian reliabel menggunakan rumus Cronbach Alpha dengan 
Prosiding The 1st National Conference on Applied Business, Education, \& Technology (NCABET)"

Unversitas Bina Bangsa 2021

DOI Article : $10.46306 /$ ncabet.v1i1.42

bantuan software SPSS 25 for windows. Menurut Nunnally sutu konstruk dikatakan reliabel jika hasil pengujian menghsilkan Cronbach Alpha $\leq$ 0,60 (Imam Ghozali,2005).

Teknik analisis data menggunakan:

1. Uji Asumsi Klasik

1) Uji normalitas atas residual dilakukan dengan uji Kolmogrov-Smirnov dengan bantuan softwareSPSS 25 for windows.

2) Uji multikolinearitas bertujuan untuk mendeteksi adanya multikolinearitas dengan melihat tolerance dan Varians Inflation Factor (VIF) yang dilakukan dengan bantuan softwareSPSS 25 for windows.

3) Uji heterokedasitisitas atas rsidual dilakukan pengamatan grafik Scaterplot dengan bantuan softwareSPSS 25 for windows.

2. Pengujian Hipotesis

Pengujian hipotesis mengunakan analisis regresi linear berganda.

\section{HASIL DAN PEMBAHASAN}

\section{Karakteristik Responden}

Dibawah ini peneliti tampilkan karakteristik responden penelitian.

Tabel 1: gambaran Umum Karakteristik Responden

\begin{tabular}{|c|c|c|c|}
\hline Karakteristik & Keterangan & $\begin{array}{l}\text { Jumlah } \\
\text { (orang) }\end{array}$ & $\begin{array}{c}\text { Persentase } \\
(\%)\end{array}$ \\
\hline \multirow[t]{3}{*}{ Jenis Kelamin } & Laki-laki & 40 & 40 \\
\hline & Perempuan & 56 & 56 \\
\hline & Jumlah & 96 & 96 \\
\hline \multirow[t]{7}{*}{ Usia } & 17-20 Tahun & 46 & 46 \\
\hline & 21-25 Tahun & 22 & 22 \\
\hline & 26-30 Tahun & 15 & 15 \\
\hline & 31-35 Tahun & 6 & 6 \\
\hline & 36-40 Tahun & 5 & 5 \\
\hline & $>40$ Tahun & 2 & 2 \\
\hline & Jumlah & 96 & 96 \\
\hline \multirow[t]{7}{*}{ Tingkat Pendidikan } & SMA/Sederajat & 56 & 56 \\
\hline & Diplomat (D3) & 10 & 10 \\
\hline & Sarjana (S1) & 28 & 28 \\
\hline & Pasca Sarjana (S2) & 1 & 1 \\
\hline & Doktor (S3) & 0 & 0 \\
\hline & Laninnya & 1 & 1 \\
\hline & Jumlah & 96 & 96 \\
\hline \multirow[t]{3}{*}{ Stastus Pernikahan } & Menikah & 32 & 32 \\
\hline & Belum Menikah & 64 & 64 \\
\hline & Jumlah & 96 & 96 \\
\hline
\end{tabular}




\section{Hasil Uji Instrumen}

Hasil Uji validitas variabel yakni kualitas produk $\left(\mathrm{X}_{1}\right)$ sebanyak 6 item kuesioner dinyatakan valid karena $r_{\text {hitung }}>r_{\text {tabel }}(0,201)$, harga $\left(X_{2}\right)$ sebanyak 6 item kuesioner dinyatakan valid karena $r_{\text {hitung }}>r_{\text {tabel }}(0,201)$, lokasi $\left(X_{3}\right)$ sebanyak 6 item kuesioner dinyatakan valid karena $r_{\text {hitung }}>r_{\text {tabel }}(0,201)$, dan keputusan pembelian $(Y)$ sebanyak 10 item kuesioner dinyatakan valid karena $r_{\text {hitung }}>r_{\text {tabel }}(0,201)$.

Hasil uji reliabelitas variabel kualtas produk $\left(\mathrm{X}_{1}\right)$ sebesar 0,874 , harga $\left(\mathrm{X}_{2}\right)$ sebesar 0,877, lokasi $\left(\mathrm{X}_{3}\right)$ sebesar 0,874 dan keputusan pembelian (Y) sebesar 0,897 menunjukkan nilai yang reliabel karena nilai Cronbash's Alpha>0,60.

\section{Hasil Uji Asumsi Klasik}

a. Uji Normalitas

berdasarkan hasil output menunjukkan nilai Kolmogorov Smirnov signifikan pada $0,200>0,05$, dengan demikian residu data berdistribusi normal dan model regresi telah memenuhi asumsi normalitas.

b. Uji Multikolonieritas

berdasarkan hasil output menunjukkan nilai Tolerance pada masing-masing variabel bebas $>0,10$ dan nilai $V I F<10$. Ini menunjukkan bahwa tidak ada Multikolinieritas diantara variabel bebas.

c. Uji Heterokedastisitas

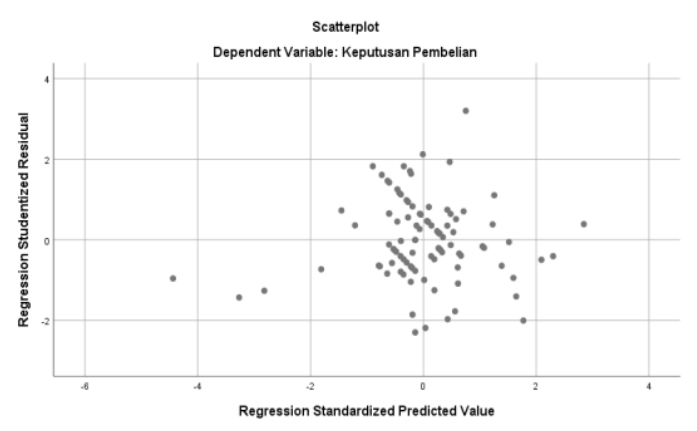

Gambar 2 Scatterplot Uji Heteroskedastisitas

Dari grafik scaterplot diatas dapat dilihat bahwa titik - titik menyebar diatas dan dibawah angka 0 pada sumbu Y, maka dapat disimpulkan tidak terjadi Heterokedasitisitas pada model regresi.

4. Uji Regresi Linear Berganda 
Analisis digunakan untuk menguji pengaruh variable independen yaitu kualitas produk $\left(\mathrm{X}_{1}\right)$, harga $\left(\mathrm{X}_{2}\right)$ dan lokasi $\left(\mathrm{X}_{3}\right)$ terhadap variabel dependen yaitu keputusan pembelian (Y).

$$
Y=3,791+0,474 X_{1}+0,289 X_{2}+0,771 X_{3}+e
$$

Penjelasan dari persamaan regresi tersebut adalah:

a : 3,791 artinya jika kualitas produk $\left(\mathrm{X}_{1}\right)$, harga $\left(\mathrm{X}_{2}\right)$ dan lokasi $\left(\mathrm{X}_{3}\right)$ sama dengan nol, maka keputusan pembelian (Y) adalah positif.

$\mathrm{b}_{1}$ : 0,474 artinya jika variabel kualitas produk $\left(\mathrm{X}_{1}\right)$ naik 1 satuan, sementara harga $\left(\mathrm{X}_{2}\right)$ dan lokasi $\left(\mathrm{X}_{3}\right)$ diasumsi tetap, maka keputusan pembelian (Y) akan meningkat 0,474 . Koefisien bernilai positif artinya terjadi pengaruh antara kualitas produk dengan keputusan pembelian Studi UMKM Mie Ayam dan Bakso Barokah Ina di Kabupaten Bungo. Jika terjadi perubahan kenaikan kualitas produk maka semakin naik penjualan bakso.

$\mathrm{b}_{2}$ : 0,289 artinya Jika variabel harga $\left(\mathrm{X}_{2}\right)$ mengalami kenikan 1 satuan, sementara variabel kualitas produk $\left(\mathrm{X}_{1}\right)$ dan lokasi $\left(\mathrm{X}_{3}\right)$ diasumsi tetap, maka keputusan pembelian (Y) akan sebesar 0,289.

b3 : 0,771 artinya Jika variabel lokasi $\left(\mathrm{X}_{3}\right)$ mengalami kenaikan 1 satuan, sementara variabel kualitas produk $\left(\mathrm{X}_{1}\right)$ dan harga $\left(\mathrm{X}_{2}\right)$ diasumsi tetap, maka keputusan pembelian akan sebesar $-0,771$.

e : eror 0,33 .

Dari analisis tersebut, maka hipotesis "1) terdapat pengaruh Kualitas produk, harga dan lokasi secara parsial terhadap keputusan pembelian UMKM Mie Ayam dan Bakso Barokah Ina di Bungo, 2) terdapat pengaruh Kualitas produk, harga dan lokasi secara Simultan terhadap keputusan pembelian UMKM Mie Ayam dan Bakso Barokah Ina di Bungo, terbukti kebenaranya.

Tabel 2 Hasil Analisis Regresi Linear Berganda

\begin{tabular}{|c|c|c|c|c|}
\hline \multicolumn{5}{|c|}{ Coefficients $^{a}$} \\
\hline \multirow{3}{*}{\multicolumn{2}{|c|}{ Model }} & \multicolumn{2}{|c|}{ Unstandardized Coefficients } & \multirow{3}{*}{$\begin{array}{c}\text { Standardize } \\
\text { d } \\
\text { Coefficients } \\
\text { Beta }\end{array}$} \\
\hline & & & & \\
\hline & & $\mathrm{B}$ & Std. Error & \\
\hline \multirow[t]{4}{*}{1} & (Constant) & 3.791 & 2.617 & \\
\hline & Kualitas Produk & .474 & .120 & .352 \\
\hline & Harga & .289 & 117 & .213 \\
\hline & Lokasi & .771 & .105 & .470 \\
\hline
\end{tabular}

Adapun Uji analisis Uji t adalah:

a. Pengujian pengaruh kualitas produk $\left(\mathrm{X}_{1}\right)$ terhadap keputusan pembelian $(\mathrm{Y})$ 
Hasil analisis terlihatdari nilai thitung (3.959) $>\mathrm{t}_{\text {tabel }}$ (1.986), sehingga $\mathrm{H}_{0}$ ditolak $\mathrm{H}_{\mathrm{a}}$ diterima. Artinya secara parsial variabel Kualitas produk berpengaruh terhadap keputusan pembelian, dalam penelitian ini kualitas harga berpengaruh terhadap keputusan pembelian studi konsumen UMKM Mie Ayam dan Bakso Barokah Ina.

b. Pengujian pengaruh harga $\left(\mathrm{X}_{2}\right)$ terhadap keputusan pembelian (Y)

Hasil analisis terlihatdari nilai thitung $(2.470)>t_{\text {tabel }}$ (1.986), sehingga $\mathrm{H}_{0}$ ditolak $\mathrm{H}_{\mathrm{a}}$ diterima. Artinya secara parsial variabel harga berpengaruh terhadap keputusan pembelian, dalam penelitian ini harga berpengaruh terhadap keputusan pembelian studi konsumen UMKM Mie Ayam dan Bakso Barokah Ina.

c. Pengujian pengaruh lokasi $\left(\mathrm{X}_{3}\right)$ terhadap keputusan pembelian (Y)

Hasil analisis terlihatdari nilaithitung $(7.313)>t_{\text {tabel }}$ (1.986), sehingga $\mathrm{H}_{0}$ ditolak $\mathrm{H}_{\mathrm{a}}$ diterima. Artinya secara parsial variabel lokasi berpengaruh terhadap keputusan pembelian, dalam penelitian ini lokasi berpengaruh terhadap keputusan pembelian studi konsumen UMKM Mie Ayam dan Bakso Barokah Ina. 


\section{Uji F (Simultan)}

Hasil analisis diperoleh nilai $F_{\text {hitung }}$ adalah 62.146 lebih besar dari $F_{\text {tabel }}$ sebesar 2,704. Sehingga $\mathrm{H}_{0}$ ditolak dan $\mathrm{H}_{\mathrm{a}}$ diterima maka dapat disimpulkan bahwa variabel kualitas produk (X1), harga (X2) dan Lokasi (X3) secara simultan berpengaruh terhadap keputusan pembelian (Y) studi.

\section{Koefisien Determinasi}

Dari hasil perhitungan diperoleh nila $\mathrm{R}$ square sebesar 0.670 atau $67,0 \%$. Besarnya nilai tersebut menunjukkan bahwa proporsi pengaruh yang diberikan masing-masing variabel yaitu variabel independen terhadap variabel dependen, dimana variabel terikat $(\mathrm{Y})$ dapat dijelaskan oleh kedua variabel bebas sebesar 67\%,sedangkna sisanya 33\% dipengaruhi oleh variabel lain diluar penelitian.

\section{KESIMPULAN DAN SARAN}

\section{Kesimpulan}

Hipotesis 1 yang menyatakan bahwa: terdapat pengaruh kualitas produk, harga dan lokasi secara parsila terhadap keputusan pembelian studi konsumen UMKM Mie Ayam dan Bakso Barokah Ina di Bungo, terbukti kebenaranya. Hipotesis 2 yang menyatakan bahwa terdapat pengaruh kualitas produk, harga dan lokasi secara simultan terhadap keputusan pembelian studi konsumen UMKM Mie Ayam dan Bakso Barokah Ina.

\section{Saran}

Pada variabel kualitas produk menyarankan untuk kualitas di pertahankan, untuk variabel harga perlu dibuat porsi yang ekonomis dan ramah dikantong, untuk variabel lokasi perlu dipertahankan.

\section{UCAPAN TERIMA KASIH}

Ucapan terima kasih pada UMKM Mie Ayam dan Bakso Barokah Ina yang telah membantu dalam penelitian ini

\section{DAFTAR PUSTAKA}

Akdon \& Ridwan. 2010. Rumus dan Data Dalam Analisis Statistika. Cet 2 Alfabeta.

Akhmad, J. 1996. “Analisis Faktor-Faktor yang Mempengaruhi Perilaku Konsumen Warung lesehan di Jalan Protokol Yogyakarta”. Jurnal STIE Widya Wiwaha Kajian Bisnis, No. 7, Hlm. 14-28. 
Prosiding The 1st National Conference on Applied Business, Education, \& Technology (NCABET)"

Unversitas Bina Bangsa 2021

DOI Article : 10.46306/ncabet.v1i1.42

Anindya Rachma Andanawari 2016.Pengaruh Harga, Lokasi, Dan Kualitas Produk Terhadap Keputusan Pembelian (Studi Kasus Pada Stove Syndicate Café Semarang).Skripsi S-1 Program Studi Manajemen, Universitas Diponegoro. Semarang.

Arikunto, Suharsimi. 2013. Prosedur Penelitian: Suatu Pendekatan Praktik. Jakarta: Rineka Cipata.

Prosedur Penelitian Suatu Pendekatan Praktek. Jakarta : PT. Rineka Cipta

Baron Himawan, Sumaryanto, Retno Susanti. 2016. Pengaruh kualitas produk, kualitas pelayanan dan lokasi terhadap keputusan pembelian konsumen di warung Mie Ayam Bakso Ajeng Karanganyar. Skripsi S-1 program studi Manajemen, Universitas Slamet Riyadi Surakarta.

Basu Swastha, DH dan Irawan. 1990. Manajemen Pemasaran Modern. Yogyakarta: Liberty. Bernandus Novian Prabowo,2018. Persepsi konsumen Terhadap Bauran Pemasaran UMKM warung makan Mie dan Bakso Pak Kliwon di Kota Semarang. Skripsi S-1 program studi Ekonomi \& Bisnis, Universitas Katolik Soegijapranata.Semarang.

Bonaventura Efrian Antyadika 2012. Analisis Pengaruh Lokasi, Harga, dan Kualitas Keputusan Pembelian (Studi pada Wong Art Bakery \& Café Semarang). Skripsi S-1 Program Studi Manajemen, Universitas Diponegoro. Semarang.

Charles Lamb, W.et.al. 2001. Pemasaran. Edisi Pertama, Salemba Empat: Jakarta.

Dwi Priyatno, 2009, 5 Jam Belajar Olah Data dengan SPSS 17, Yogyakarta.

Effendi, N. I. (2021). Model Peningkatan Kinerja Wirausaha UMKM Etnis Non-Melayu Melalui Modal Sosial di Kabupaten Bungo ( A Preliminary Research ). Jurnal Manajemen Sains, $\quad 1(2), \quad$ 166-177. https://doi.org/http://dx.doi.org/10.36355/jms.v1i2.558

Effendi, N. I., Akbar, R. M., \& Murni, Y. (2020). Shopping Orientation and Online Trust To Enhance Online Purchase Intentions With Gender Differences As Moderator. Journal of Economics, Business, and Government Challenges, 3(2), 117-126. https://doi.org/10.33005/ebgc.v3i2.124

Effendi, N. I., Harahab, D. F., \& Arisandi, D. (2018). Pengaruh Dimensi Brand Equity Terhadap Keputusan Pembelian Konsumen pada Produk Pasta Gigi Pepsodent (Studi pada Mahasiswa Fakultas Ekonomi Universitas Muara Bungo). Jurnal Aplikasi Manajemen Dan Bisnis, l(1). Retrieved from https://ojs.umbbungo.ac.id/index.php/jambis/article/view/169

Effendi, N. I., Supriyati, \& Herawati. (2021). Peningkatan Pemasaran Produk Melalui Pelatihan Disain Kemasan dan Promosi Multimedia Keripik Tempe Desa Kuamang Gading Kota 
Prosiding The 1st National Conference on Applied Business, Education, \& Technology (NCABET)"

Unversitas Bina Bangsa 2021

DOI Article : 10.46306/ncabet.v1i1.42

Jambi. Jurnal Masyarakat Mandiri, 5(4), 1856-1865. https://doi.org/https://doi.org/10.31764/jmm.v5i4.5062

Feri Septian 2019."Pengaruh Kualitas Pelayanan, Harga dan Kualitas Produk terhadap Kepuasan Pelanggan Southera Coffe Palembang. Skripsi S-1 Program Studi Manajemen, Universitas Muhammadiyah Palembang. Palembang.

Ghozali, Imam. 2006. Aplikasi Analisis Multivariate Dengan Program SPSS. CetakanKeempat. Semarang: Badan Penerbit Universitas Diponegoro.

2009. Aplikasi Analisis Multivariate Dengan Program SPSS. Edisi Keempat. Semarang: Badan Penerbit Universitas Diponegoro.

2011. "Aplikasi Analisis Multivariate Dengan Program SPSS". Edisi Keempat. Semarang: Badan Penerbit Universitas Diponegoro.

Kotler, Philip. 1985. Dasar-dasar Pemasaran. Jilid 1. Jakarta: PT. Midas Surya Grafindo. (2000). Prinsip - Prinsip Pemasaran Manajemen, Jakarta: Prenhalindo.

2005.Manajemen Pemasaran. Jilid 1 dan 2.Jakarta : PT IndeksKelompok Gramedia.

Kotler, Philip dan Keller, 2007, Manajemen Pemasaran, Jilid I, Edisi Kedua belas, PT. Indeks, Jakarta

Kotler, Philip dan Gary Amstrong, 2006, Prinsip-Prinsip Pemasaran, Jilid 1, Edisi 12, Terjemahan: Bob Sabran, M.M, Jakarta: Erlangga.

Luthfan Fazari Harsanto ${ }^{1}$ dan Drs. Wahyu Hidayat, M.Si²). "Pengaruh Kualitas Produk, Harga Dan Lokasi Terhadap Keputusan Pembelian (Pada Ukm Martabak Mas Ipung Di Perumahan Plamongan Indah Semarang”. Skripsi S-1 Program Studi Manajemen, Universitas Diponegoro.Semarang.

M. Rizwar Ghazali 2010. “Analisis Pengaruh Lokasi, Promosi Dan Kualitas Layanan Terhadap Keputusan Membeli ( Warnet (Warung Internet) Xyz Jl.Singosari, Kota Semarang )”. Skripsi S-1 Program Studi Manajemen, Universitas Diponegoro.Semarang.

Mayuni Siagian 2019.Pengaruh kualitas produk, harga, dan kualitas pelayanan terhadap kepuasan konsumen (studi konsumen Café BOS KOFFIE EAT Bungo). Skripsi S-1 Program Studi Manajemen, Universitas Muara Bungo.Jambi.

Miftahur, M., Effendi, N. I., \& Roni, K. A. (2018). Pengaruh Promosi, Harga, Dan Kualitas Pelayanan Terhadap Kepuasan Pelanggan Percetakan Di Kabupaten Bungo. Jurnal Aplikasi Manajemen Dan Bisnis, 1(1). Retrieved from https://ojs.umbbungo.ac.id/index.php/jambis/article/view/171

Mischitelli, V.2000. Your New Restaurant (2 ${ }^{\text {nd }}$ ed.). Canada: Adams Media Cooperation. 
Prosiding The 1st National Conference on Applied Business, Education, \& Technology (NCABET)"

Unversitas Bina Bangsa 2021

DOI Article : $10.46306 /$ ncabet.v1i1.42

Rambat, Lupiyoadi. 2006 Manajemen Pemasaran Jasa : Teori dan Praktek. Jakarta: PT Salemba Empat.

Stanton, William,J.2006.Prinsip Pemasaran, Edisi Ke tujuh, jilid 2, cetakan ke empat,Gelora Aksara Pratama.

Sugiyono. 2009.MetodePenelitian Kuantitatif.Bandung: Alfabeta 2012. Metode Penelitian Pendidikan Pendekatan Kuantitatif, Kualitatif dan $R \&$ D. Bandung: Alfabeta. 2014.Metode Penelitian Pendidikan Pendekatan Kuantitatif,Kualitatif Dan $R \& D$. Bandung: Alfabeta. 